\title{
PENGEMBANGAN LEMBAR KERJA SISWA BERBASIS PENDEKATAN KONTEKSTUAL PADA MATERI LINGKARAN UNTUK SISWA SMP
}

\author{
Reva Gitriani ${ }^{1}$, Siti Aisah ${ }^{2}$, Heris Hendriana ${ }^{3}$, Indri Herdiman ${ }^{4}$ \\ 1,2,3,4 Program Studi Pendidikan Matematika IKIP Siliwangi Bandung
}

\begin{abstract}
This research aims to develop learning tools of mathematics junior high school with a contextual approach as a tool for learning mathematics. The subjects are 34 students in the eighth grade of junior high school. The research method used is development research by referring to ADDIE development model which consists of five stages, namely analysis, design, development, implementation, and evaluation. The instruments are validation sheets of student worksheet, questionnaires, and test results. Results of this research are: (1) the validation result of student worksheet is in very good category; (2) the result of a questionnaire of student response is in very good category; and (3) the result of the student's learning test is in a good category. So that, student worksheet is feasible from the aspect of validity, practicality, and effectiveness.
\end{abstract}

Keyword: Student worksheet; Circle material; Contextual approach

\section{PENDAHULUAN}

Matematika adalah ilmu pengetahuan yang memegang peran penting bagi kehidupan dan pengetahuan lainnya. Salah satu tujuan disampaikannya pelajaran matematika yaitu untuk mempersiapkan siswa agar dapat diaplikasikan dalam kehidupan karena matematika ada dalam setiap aspek kehidupan. Selain itu matematika juga diperlukan untuk mengembangkan dan mengukur kemampuan siswa untuk berfikir secara logis, kritis, sistematis dan objektif. Seperti yang dikatakan oleh Hendriana (2013) bahwa untuk meningkatkan mutu pendidikan dan individu seseorang dapat diwujudkan salah satunya dengan pendidikan matematika yang dapat kita ajarkan dibangku persekolahan.

Kemampuan tersebut dapat dikembangkan, salah satunya dengan mempelajari materi lingkaran. Materi lingkaran merupakan bagian dalam pelajaran matematika SMP kelas VIII yang wajib dipelajari dan dikuasai oleh siswa karena terdapat pada standar isi kurikulum 2013. Memahami unsur-unsur, keliling dan luas lingkaran menjadi salah satu KD (Kompetensi Dasar) yang harus dicapai oleh siswa pada materi lingkaran (Kemendikbud, 2016). Diharapkan dengan menguasai kompetensi dasar tersebut, peserta didik dapat menentukan unsur-unsur dari lingkaran serta dapat menyelesaikan 
permasalahan lingkaran terkait keliling dan luasnya.

Pada pembelajaran matematika di sekolah, guru harus mengupayakan pengorganisasian materi matematika agar peseta didik merasa tidak kesulitan dalam pembelajaran dan membuat aktif serta dapat menemukan konsep sendiri pada materi matematika. Oleh karena itu, guru perlu memahami karakteristik, kecerdasan, dan kemampuan yang dimiliki masing-masing siswanya agar dapat mengarahkan siswa pada pembelajaran yang seharusnya (Fauzan \& Herman, 2016). Keterlibatan siswa ini dapat terjadi bila bahan yang disusun dan disajikan itu bermakna bagi siswa, sehingga interaksi antara pendidik dan peserta didik menjadi efektif (Kurniawan, 2016). Upaya ini dapat direalisasikan dengan adanya bahan ajar berupa LKS yang disusun sesuai dengan perkembangan peserta didik. Hal ini senada dengan Prastowo (2013), yang memaparkan fungsi LKS antara lain: (1) sebagai produk yang dapat mempermudah peran pendidik, juga dapat membuat siswa lebih aktif; (2) peserta didik lebih mudah memahami pembelajaran; (3) sebagai hasil atau produk yang dapat bergunakan untuk berlatih; dan (4) mempermudah pendidik atau juga siswa dalam pelaksanaan pembelajaran.

Guru sebagai seorang fasilitator harus mengupayakan agar bahan ajar dapat membuat peserta didik lebih aktif, kreatif, serta mampu melatih kemandirian belajar mereka. Seperti yang dikatakan Ramdani (2012), bahwa secara keseluruhan bahan ajar sangat penting bagi kegiatan pembelajaran. Melalui LKS, banyak kegiatan yang dilakukan peserta didik dalam mengerjakan soal latihan dengan tujuan mempermudah mereka dalam memahami suatu materi. Perlu adanya pengembangan LKS agar LKS lebih kreatif dan tidak sama seperi biasanya. Seperti yang dikatakan Herdiman (2017), bahwa pendekatan pembelajaran dapat berupaya membantu siswa menjadi aktif untuk mengembangkan daya nalar matematik siswa sehingga mampu mengembangkan dan mengevaluasi argumentasi. Salah satu pendekatan pembelajaran yang bisa digunakan, yaitu pendekatan kontekstual.

Sanjaya (2006) menjelaskan bahwa pendekatan kontekstual ialah metode yang mendorong siswa untuk menemukan konsep secara mandiri pada pembelajaran yang sedang diajarkan dan menghubungkan materi tersebut pada kehidupan nyata yang dapat ditemui dalam kehidupan. Pada pendekatan kontekstual terdapat tujuh tahap pembelajaran; (1) konstruksivisme, (2) masyarakat belajar, (3) menemukan, (4) pemodelan, (5) bertanya, (6) refleksi, dan (7) penilaian sebenarnya. 
Terkait dengan pemaparan yang telah disampaikan, penelitian ini bertujuan: (1) mengembangkan LKS materi lingkaran berbasis pendekatan kontekstual untuk siswa SMP; (2) mengetahui kelayakan lembar kerja siswa berbasis pendekatan kontekstual dilihat dari aspek kevalidan, kepraktisan, dan efektivitasnya. Penelitian ini dilakukan untuk mengetahui bagaimana mengembangkan LKS supaya bisa lebih efektif dan inovatif. Manfaat dari penelitian ini antara lain: (1) bagi siswa, LKS yang dikembangkan dapat menjadi acuan sebagai petunjuk siswa dalam menemukan konsep dan sub pokok materi lingkaran, (2) bagi guru, dapat berguna sebagai wacana untuk mengembangkan LKS agar lebih meningkatkan kreativitas guru dalam membuat bahan ajar, dan (3) bagi peneliti lain, dapat menjadi acuan untuk mengembangkan LKS matematika dengan materi lain ataupun jenjang lain serta menambah wawasan mengenai LKS dan pengembangannya.

\section{METODE PENELITIAN}

Penelitian ini merupakan penelitian yang berfokus kepada pengembangan atau research and development. Bahan yang dikembangkan dalam penelitian ini berupa LKS untuk siswa SMP materi lingkaran berbasis pendekatan kontekstual dengan merujuk pada model pengembangan ADDIE yang terdiri dari lima tahap yaitu analysis, design, development, implementation, dan evaluation.

Pada tahap analysis terdapat 3 proses analisis, yaitu analisis kebutuhan, analisis kurikulum, dan analisis karakteristik siswa. Analisis kebutuhan, yaitu tahap ditentukannya bahan ajar mana yang perlu dikembangkan. Analisis kurikulum, pada tahap ini dikaji standar kompetensi dan kompetensi dasar mana yang harus dikuasai siswa dalam materi lingkaran. Analisis karakteristik siswa, pada tahap ini dilakukan observasi kelas untuk melihat peningkatan kognitif siswa.

Pada tahap design terdapat 2 kegiatan, yaitu rancangan penyusunan LKS dan rancangan instrumen kelayakan LKS. LKS dirancang dengan memperhatikan struktur pembuatan LKS pada 6 bagian yaitu judul penamaan, petunjuk penggunaan, kompetensi, informasi pendukung, penugasan dan langkah-langkah pengerjaan LKS, dan penilaian. Sedangkan perancangan instrumen kelayakan LKS antara lain validasi LKS, angket respon siswa, dan tes hasil belajar siswa.

Pada tahap development, dikembangkan LKS yang sudah terencana pada tahap 
design (perancangan). Untuk melihat kelayakan LKS yang sudah dibuat, terlebih dahulu dilakukan validasi LKS oleh validator menggunakan lembar validasi LKS. Kelayakan LKS dapat ditijau dari hasil validasi tersebut yang dilihat dari aspek kevalidan dan acuan untuk mengambil keputusan apakah LKS layak diujicobakan atau tidak.

Pada tahap implementation, yaitu tahap uji coba LKS di kelas. Berdasarkan tahap ini dapat diketahui kelayakan LKS yang ditinjau dari aspek kepraktisan dan keefektifan melaui pengisian angket dan tes.

Pada tahap evaluation, dilakukan analisis hasil angket dan tes siswa. Pada tahap ini dapat diketahui keunggulan dan kelemahan dari LKS yang digunakan pada saat pembelajaran. Selanjutnya, dilakukan perbaikan dan penyempurnaan berdasarkan kekurangan dan kesalahan yang terjadi pada saat pembelajaran.

Penelitian ini menggunakan pendekatan kuantitatif, dimana data hasil penelitian dipaparkan dalam bentuk angka. Data kuantitatif tersebut didapat dari hasil validasi LKS oleh validator, hasil angket, hasil tes belajar siswa. Untuk pengumpulan ketiga data tersebut digunakan beberapa instrumen, yaitu: (1) lembar validasi, untuk melihat kevalidan LKS dilihat dari aspek kevalidan, (2) angket, untuk mengetahui kelayakan LKS dilihat dari aspek kepraktisan, dan (3) tes hasil belajar siswa, untuk melihat kelayakan LKS dilihat dari aspek keefektifan.

Tahapan analisis dilakukan dengan beberapa tahapan. Pertama, kevalidan LKS. Hasil validasi yang telah diisi oleh validator dianalisis dengan langkah-langkah, (1) menghitung rerata total skor masing-masing aspek yang mencakup aspek ketepatan isi, kemenarikan isi, kecukupan isi, kualitas keseluruhan, desain LKS, dan desain isi mengacu pada rumus yang dimodifikasi oleh Norsanty \& Chairani (2016), (2) rerata total skor yang telah dihitung dikonversikan menjadi data kualitatif berdasarkan pedoman konversi pada Tabel 1 yang dimodifikasi dari Widoyoko (2009).

Tabel 1. Pedoman konversi rata-rata skor validasi

\begin{tabular}{cc}
\hline Interval & Kategori \\
\hline $\bar{x}>M_{i}+1,8 \mathrm{Sb}_{\mathrm{i}}$ & Sangat Baik \\
$M_{i}+0,6 \mathrm{Sb}_{\mathrm{i}}<\bar{x} \leq M_{i}+1,8 \mathrm{Sb}_{\mathrm{i}}$ & Baik \\
$M_{i}-0,6 \mathrm{Sb}_{\mathrm{i}}<\bar{x} \leq M_{i}+0,6 \mathrm{Sb}_{\mathrm{i}}$ & Cukup \\
$M_{i}-1,8 \mathrm{Sb}_{\mathrm{i}}<\bar{x} \leq M_{i}-0,6 \mathrm{Sb}_{\mathrm{i}}$ & Kurang \\
$\bar{x} \leq M_{i}-1,8 \mathrm{Sb}_{\mathrm{i}}$ & Sangat Kurang \\
\hline
\end{tabular}

dengan, $M_{i}=\frac{1}{2}$ x (skor maksimal ideal + skor minimal ideal), $\mathrm{Sb}_{\mathrm{i}}=\frac{1}{6} \mathrm{x}$ (skor maksimal ideal - skor minimal ideal), dan $\bar{x}=$ rataan skor, (3) LKS dinyatakan layak dilihat dari 
aspek kevalidan. Apabila hasil analisis validasi tergolong baik atau sangat baik, maka hasil penilaian LKS oleh validator dapat dikategorikan rata-rata skor seperti pada Tabel 2.

Tabel 2. Kategori Rata-rata Skor Validitas LKS

\begin{tabular}{cc}
\hline Interval & Kategori \\
\hline $\bar{x}>3,4$ & Sangat Baik \\
$2,8<\bar{x} \leq 3,4$ & Baik \\
$2,2<\bar{x} \leq 2,8$ & Cukup \\
$1,6<\bar{x} \leq 2,2$ & Kurang \\
$\bar{x} \leq 1,6$ & Sangat Kurang \\
\hline
\end{tabular}

Kedua, analisis kepraktisan. Hasil angket yang didapat dilanjutkan untuk dianalisis dengan langkah-langkah, (1) menghitung rerata total skor dari 34 siswa (responden), (2) rerata total skor analisis tersebut dikonversikan kembali menjadi data kualitatif berdasarkan pedoman konversi di Tabel 1. Skor maksimal merupakan skor tertinggi yang didapat dari hasil angket, dan skor minimal adalah skor terendah yang diperoleh pada hasil angket respon siswa. LKS dikatakan layak dilihat dari aspek kepraktisan apabila hasil analisis angket berada pada kategori baik atau sangat baik. Adapun kategori rerata total skor disajikan pada Tabel 3.

Tabel 3. Kategori Rata-rata Total Skor Angket

\begin{tabular}{cc}
\hline Interval & Kategori \\
\hline $\bar{x}>17$ & Sangat Baik \\
$14<\bar{x} \leq 17$ & Baik \\
$11<\bar{x} \leq 14$ & Cukup \\
$8<\bar{x} \leq 11$ & Kurang \\
$\bar{x} \leq 8$ & Sangat Kurang \\
\hline
\end{tabular}

Ketiga, analisis keefektifan. Hasil tes yang telah didapat kemudian dianalisis dengan menghitung skor yang didapat siswa dari tes tersebut menggunakan pedoman penskoran tes hasil belajar. Selanjutnya, menentukan nilai akhir tes yang didapat dari skor yang diperoleh dibagi skor maksimal dikalikan 100 .

Selanjutnya, menghitung banyaknya siswa yang lulus pada tes tersebut menggunakan Kriteria Ketuntasan Minimal (KKM) yang telah ditetapkan, yaitu 70 . Persentase ketuntasan klasikal dihitung menggunakan rumus berikut.

$$
P=\frac{T}{n} \times 100 \%
$$

dengan, $P=$ persentase ketuntasan klasikal, $T=$ banyak siswa yang tuntas, dan $n=$ banyak 
siswa.

Persentase ketuntasan yang telah dihitung dimuat menjadi data kualitatif. LKS dikatakan layak dari aspek keefektifan, jika persentase ketuntasan klasikal tergolong baik atau sangat baik. Kategori persentase ketuntasan klasikal bisa dilihat pada Tabel 4 menurut Widoyoko (2009).

Tabel 4. Kategori Persentase Ketuntasan Klasikal

\begin{tabular}{cc}
\hline Interval (\%) & Kategori \\
\hline$P>80$ & Sangat Baik \\
$70<P \leq 80$ & Baik \\
$60<P \leq 70$ & Cukup \\
$50<P \leq 60$ & Kurang \\
$P \leq 50$ & Sangat Kurang \\
\hline
\end{tabular}

\section{HASIL DAN PEMBAHASAN}

Proses pengembangan LKS berbasis pendekatan kontekstual diawali dengan proses kajian teoritik, hasil penelitian yang relevan, dilanjutkan dengan observasi untuk mendapatkan informasi mengenai bahan ajar dan kurikulum yang digunakan di sekolah, dan mengenai karakteristik siswa. Berdasarkan informasi yang didapat maka dibuatlah rancangan LKS, kelayakan LKS yang disusun pada tahap perancangan. Kemudian dilakukan pengembangan terhadap LKS sehingga menjadi LKS yang dinyatakan layak berdasarkan aspek kevalidan berdasarkan hasil validasi berikut:

Tabel 5. Hasil Validitas LKS

\begin{tabular}{ccc}
\hline No & Validator & Total skor yang didapat \\
\hline 1 & Guru Matematika & 38 \\
2 & Dosen Matematika & 39 \\
3 & Ahli Bahasa & 36 \\
\hline & Jumlah skor & 113 \\
\hline Rata-rata & 3.77 \\
\hline
\end{tabular}

Berdasarkan hasil validitas LKS yang sudah dihitung dari tiga validator, maka LKS dinyatakan sangat baik sesuai Tabel 2. LKS dalam penelitian ini dikatakan layak dan valid karena telah dianalisis oleh validator tentang penulisan LKS, kesesuaian pembahasan dalam LKS dengan materi, dan bahasa yang digunakan pada LKS. Setelah itu LKS yang telah dinyatakan layak berdasarkan aspek kevalidan, diimplementasikan atau diujicobakan di kelas VIII pada salah satu SMP Negeri di Batujajar. Pada saat uji coba LKS, dilakukan kegiatan observasi oleh seorang observer untuk melihat pelaksanaan pembelajaran di kelas menggunakan LKS tersebut selama tiga kali pertemuan. Pada 
pertemuan keempat, dilaksanakan tes hasil belajar siswa dan pengisian angket respon siswa. Hasil tes dan hasil angket tersebut digunakan sebagai data untuk mengetahui kelayakan LKS berdasarkan aspek keefektifan dan kepraktisan.

Setelah tahap uji LKS dilaksanakan, dilanjutkan dengan tahap evaluasi. Pada tahap ini, dilakukan analisis data hasil tes dan angket respon untuk mengetahui kelayakan LKS ditinjau dari aspek kepraktisan dan keefektifan. Pada uji kepraktisan, siswa diminta menilai melalui butir-butir pernyataan mengenai kemenarikan LKS, kemudahan memahami LKS, dan kemanfaatan LKS tersebut. Sedangkan pada uji keefektifan dilakukan tes akhir hasil belajar siswa. Jika hasil angket dan tes belajar siswa sudah tergolong baik atau sangat baik maka LKS layak untuk digunakan. Hasil analisis angket pada Tabel 6, diterapkan ke dalam rumus pedoman konversi rerata total skor angket yang ada di Tabel 1 dan dikategorikan berdasarkan Tabel 3.

Tabel 6. Validitas Respon Siswa

\begin{tabular}{ccccccc}
\hline $\begin{array}{c}\text { Banyak } \\
\text { Siswa }\end{array}$ & $\begin{array}{c}\text { Total } \\
\text { Skor }\end{array}$ & $\begin{array}{c}\text { Rata-rata } \\
\text { Total skor }(\overline{\boldsymbol{x}})\end{array}$ & $\begin{array}{c}\text { Skor } \\
\text { Maks }\end{array}$ & $\begin{array}{c}\text { Skor } \\
\text { Min }\end{array}$ & $\begin{array}{c}\text { Mean } \\
\text { Ideal }\left(\boldsymbol{M}_{\boldsymbol{i}}\right)\end{array}$ & $\begin{array}{c}\text { Simpangan } \\
\text { Baku }\left(\boldsymbol{S}_{\boldsymbol{i}}\right)\end{array}$ \\
\hline 34 & 583 & 17.14 & 20 & 5 & 12.5 & 2.5 \\
\hline
\end{tabular}

Berdasarkan hasil analisis, maka rataan total skor angket yaitu sebesar 17,14. Hasil menunjukkan LKS tergolong kategori sangat baik ditinjau dari aspek kepraktisan, sehingga LKS dapat dikatakan layak untuk digunakan. Adapun hasil analisis tes belajar siswa, didapatkan bahwa 25 siswa tuntas (74\%) sedangkan 9 siswa tidak tuntas (26\%).

Dengan demikian, hasil analisis tes belajar siswa dengan persentase ketuntasan klasikal sebesar 74\% termasuk kategori baik. Berdasarkan pada aspek keefektifan, maka LKS dapat dikatakn layak digunakan.

Hasil penelitian di atas menunjukkan bahwa LKS materi lingkaran yang berbasis pembelajaran kontekstual, layak digunakan. Ditinjau dari aspek kepraktisan, dapat dikatakan bahwa LKS materi lingkaran berbasis pendekatan kontekstual praktis digunakan oleh siswa sehingga pembelajaran dapat terlaksana dengan baik, aktif, dan kreatif. Hal ini sejalan dengan teori yang dipaparkan oleh Bruner bahwa guru harus memberi kesempatan kepada siswa untuk menemukan konsep atau aturan-aturan ataupun teori dan sebagainya agar siswa lebih aktif dan kreatif sehingga proses pembelajaranpun berjalan dengan baik. Berdasarkan kepraktisannya itu, maka LKS mampu membimbing siswa menemukan sendiri konsep lingkaran (Norsanty \& Chairani, 2016).

LKS juga efektif dan praktis digunakan di sekolah karena mampu membuat siswa 
mengkonstruksi (membangun) sendiri pengetahuannya tentang unsur-unsur lingkaran serta keliling dan luas lingkaran. Selaras dengan pendapat Bruner, bahwa guru harus mengarahkan atau memandu siswa-siswanya sehingga mereka dapat membangun pengetahuannya secara mandiri, bukan karena diberitahu atau diajari melalui memori hafalan (rote memorization) (Norsanty \& Chairani, 2016). Efektif atau tidaknya LKS ini dibuktikan berdasarkan hasil tes belajar siswa yang menunjukkan bahwa sebanyak 25 dari 34 siswa mampu memahami materi lingkaran yang ada di LKS tersebut. Hal ini senada dengan penjelasan yang dipaparkan oleh Trianto (2010), bahwa LKS berguna untuk mengoptimalkan pemahaman siswa dengan kegiatan-kegiatan yang mendasar yang sesuai dengan tujuan dan indikator pencapaiannya

\section{SIMPULAN DAN SARAN}

Berdasarkan hasil dan pembahasan yang dipaparkan di atas, maka disimpulkan bahwa pengembangan LKS materi lingkaran berbasis pembelajaran kontekstual untuk siswa SMP kelas VIII yang dikembangkan merujuk pada model pengembangan ADDIE, layak digunakan. Ditinjau dari: (1) hasil validasi LKS tergolong pada kategori sangat baik, sehingga LKS dapat dikatakan layak dilihat dari aspek kevalidan; (2) hasil angket tergolong pada kategori sangat baik, sehingga LKS dapat dikatakan layak ditinjau dari aspek kepraktisan; dan (3) tes hasil belajar siswa tergolong pada kategori baik, sehingga LKS dinyatakan layak ditinjau dari aspek keefektifan. Karena LKS telah dinyatakan valid, praktis dan efektif maka dari itu LKS dapat digunakan dalam proses pembelajaran siswa di sekolah formal maupun nonformal pada materi lingkaran.

Berdasarkan simpulan yang dikemukakan, LKS materi lingkaran berbasis pendekatan kontekstual untuk siswa SMP kelas VIII dapat dijadikan alternatif pendukung pembelajaran yang dapat berguna untuk guru-guru di sekolah sebagai salah satu upaya untuk meningkatkan kualitas dan mutu pembelajaran. Penggunaan materi, pendekatan, dan model pengembangan lain yang lebih bervariasi sangat disarankan untuk peneliti selanjutnya agar dapat mengeksplor pengembangan LKS lebih dalam lagi. 


\section{DAFTAR RUJUKAN}

Fauzan, \& Herman, T. (2016). Peningkatan kemampuan penalaran matematis dan selfesteem siswa kelas V melalui strategi multiple intelligence. Jurnal Pendidikan Dasar, 8(2), 152.

Hendriana, H. (2013). Membangun kepercayaan diri siswa melalui pembelajaran matematika humanis. Bandung: Seminar STKIP Siliwangi Tidak Dipublikasikan.

Herdiman, I. (2017). Penerapan pendekaran open-ended untuk meningkatkan penalaran matematika siswa SMP. JES-MAT, 3(2), 195-204.

Kemendikbud. (2016). Permendikbud Nomor 21 Tahun 2016 tentang Standar Isi Pendidikan Dasar dan Menengah. Jakarta: Kemendikbud.

Kurniawan, A. P. (2016). Pengembangan aplikasi pembentukan kelompok cooperative learning menggunakan visual basic. JRPM (Jurnal Review Pembelajaran Matematika), 1(2), 192-208. doi: https://doi.org/10.15642/jrpm.2016.1.2.192-208

Norsanty, U. O., \& Chairani, Z. (2016). Lingkaran berbasis pembelajaran guided discovery untuk siswa smp kelas VIII. Math Didactic: Jurnal Pendidikan Matematika, 2(1), 19-20.

Prastowo, A. (2013). Panduan kreatif membuat bahan ajar inovatif. Yogyakarta: Diva Press.

Ramdani, Y. (2012). Pengambangan instrumen dan bahan ajar untuk meningkatkan kemampuan komunikasi, penalaran, dan koneksi matematis dalam konsep integral. Jurnal Penelitian Pendidikan, 13(1), 44-52.

Sanjaya, W. (2006). Strategi pembelajaran berorientasi standar proses pendidikan. Jakarta: Kencana Pranada Media Group.

Trianto. (2010). Mendesain model pembelajaran inovatif-progresif konsep, landasan, implementasinya pada kurikulum tingkat satuan pendidikan (KTSP). Jakarta: Kencana Pranada Media Group.

Widoyoko, S. E. P. (2009). Evaluasi program pembelajaran panduan praktis bagi pendidik dan calon pendidik. Yogyakarta: Pustaka Pelajar. 